\title{
Assessment of Adaptable Urban Environment for Public Art Integration through Observation Study: Johor Bahru City Centre
}

\author{
Muhammad Falihin Jasmi ${ }^{1 *}$, Nik Hanita Nik Mohamad ${ }^{2}$ \\ ${ }^{1}$ Institute of Graduate Studies, Faculty of Architecture, Planning and Surveying, Universiti Teknologi MARA (UiTM) Shah Alam, Selangor, \\ Malaysia \\ ${ }^{2}$ Centre of Studies in Landscape Architecture, Faculty of Architecture, Planning and Surveying, Universiti Teknologi MARA (UiTM) Puncak Alam, \\ Selangor, Malaysia.
}

\begin{abstract}
In Malaysia, there is an unprecedented interest in public art, especially in the major cities. Notwithstanding the increasing interest, however, the rationale and placement of it is extensively debatable. Therefore, this paper aims to examine the adaptable urban environment for public art integration towards enhancing the image of Johor Bahru City Centre, through an observation study. It identifies the urban morphology that substantiates development of suitability plan for public art placement, whilst refining legibility, connectivity, and urban fabric. The outcome of this paper is hoped to support related professionals in defining guidelines and strategies for public art, towards liveable city.

(C) 2016. The Authors. Published for AMER ABRA by e-International Publishing House, Ltd., UK. This is an open access article under the CC BYNC-ND license (http://creativecommons.org/licenses/by-nc-nd/4.0/).

Peer-review under responsibility of AMER (Association of Malaysian Environment-Behaviour Researchers), ABRA (Association of Behavioural Researchers on Asians) and CE-Bs (Centre for Environment-Behaviour Studies), Faculty of Architecture, Planning \& Surveying, Universiti Teknologi MARA, Malaysia.
\end{abstract}

Keywords: Public Art; Urban Environment; Adaptable Environment; Urban Morphology

\subsection{Introduction}

Public art had evolved and established in a variety of forms and materials; from an integrated artwork on the building surface (mural and graffiti), free standing sculpture, statue, and monument, towards modern technology-integrated artwork such as digital display and vertical greenery. Instead of standing as a landmark in a city centre, series of public art could provide a visual sequence that improves connections between spaces, enhance the visual

\footnotetext{
${ }^{*}$ Corresponding author. Tel.: +013-4496946

E-mail address: falihinjasmi@gmail.com
}

2398-4287 @ 2016. The Authors. Published for AMER ABRA by e-International Publishing House, Ltd., UK. This is an open access article under the CC BY-NC-ND license (http://creativecommons.org/licenses/by-nc-nd/4.0/).

Peer-review under responsibility of AMER (Association of Malaysian Environment-Behaviour Researchers), ABRA (Association of Behavioural Researchers on Asians) and CE-Bs (Centre for Environment-Behaviour Studies), Faculty of Architecture, Planning \& Surveying, Universiti Teknologi MARA, Malaysia.

DOI: http://dx.doi.org/10.21834/e-bpj.v1i4.383 
experience for the public and consequently help them to understand and memorize the legibility of the city. It contributes to an enhancement of public realm, successful place making and development of cultural and social capital (Australian Institute of Landscape Architecture, 2010). The public art's impact on the community is priceless, as it adds to the understanding of a place, its past, and current physical environment and cultural fabric (Nurul Izzah et.al, 2014). Additionally, public art boosts city economy and give benefits to the community. According to City of San Diego Commission for Arts and Culture (2004), a lively public art program has sustained economic strength and engrossed individuals and companies, which can promote and facilitate prosperity for the citizens.

In Malaysia, there is an unprecedented interest and excitement in public art, especially in the major cities of Kuala Lumpur, Georgetown, Ipoh, Shah Alam and Johor Bahru. Notwithstanding the increasing interest, however, the rationale, locality, and placement of public art in Malaysia are essential issues that need to be addressed, particularly in the realm of built environment. Cardiff County Council (2005) stated that public art should be placed in publicly accessible and visible spaces, which is open for public appreciation and interaction. Meanwhile, Irish Museum of Modern Art (2008) cited that the establishment of public art often responds to the public place and its specification; it's setting, current site activity, significance and history. Currently, public art in Malaysia are mostly installed to fill the empty and lost urban spaces which overturn the objective of public art as a public object (Flynn, 2013) thus leading to vandalism. Furthermore, several public art implemented at the chosen sites are placed just for the sake of beautification without responding to any narration of symbolism of history, celebration of an event or other humanistic factors. Therefore, this paper aims to examine the best adaptable urban environment for public art integration towards enhancing the image of Johor Bahru City Centre through an Observation study. The objectives of this paper are (a) to determine the characteristic and morphology of study area that significantly contributes to the integration of public art program and (b) to establish suitability plan for public art placement towards a liveable city.

\subsection{Case Study: Johor Bahru City Centre}

Johor Bahru City Centre is chosen as the study area for its strategic location at the southern entrance of Peninsular Malaysia (via land), which provides the first impression among both the international and local tourists (Fig.1). The primarily invaluable multicultural and prosperous history of Johor Bahru offers cultural significance for public art purposes. As provided in Iskandar Malaysia Johor Bahru City Centre Physical Planning Initiatives 2006 to 2025, Objective 10 stated; "Promoting public art that reflects the identity of a city and it is the voice of the local communities and helps to strengthen relationships between diverse groups." In this light, the paper will cover a detailed assessment of the character of Johor Bahru City Centre; it's social, cultural and environmental aspects that play a significant role in establishing an adaptable urban environment for public art integration.

(a

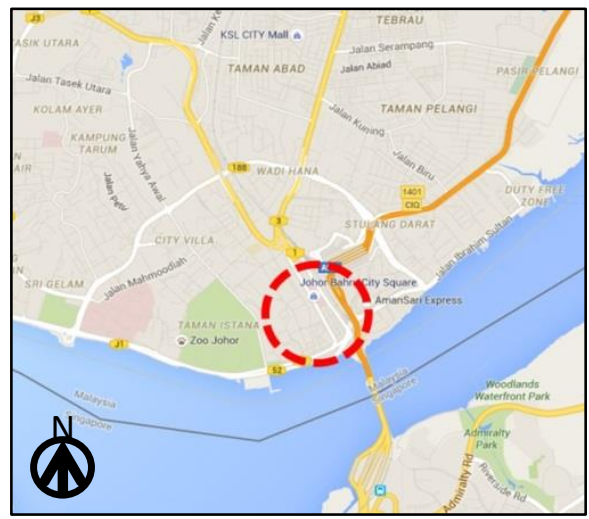

(b

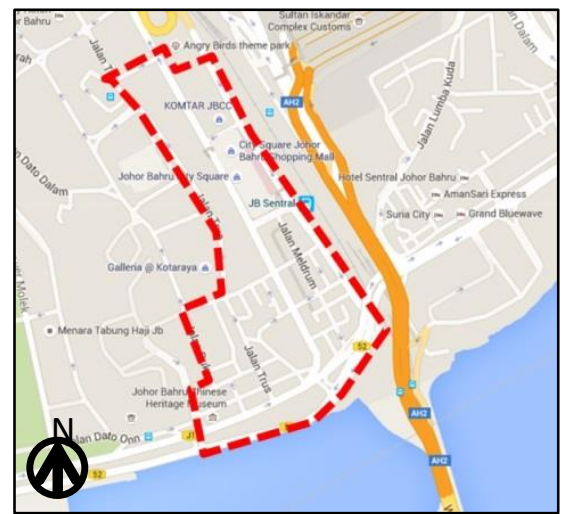

Fig. 1. (a) Key Plan; (b) Location Plan of study area (Source: Google Maps,2016). 


\subsection{Literature Review}

\subsection{Public Art in Malaysia: An Overview}

Presently, several local authorities in Malaysia had started to organize public art programs that encourage public participation. It is a respectable effort to educate and generate awareness among the society on public art. For instance, Dewan Bandaraya Kuala Lumpur (DBKL) had launch artwork and sculpture competition for public participation in 2014, which aims to improve Kuala Lumpur urban design image and way-finding. Additionally, Penang State Tourism and Development Office with the collaboration of Penang Global Tourism and appointed artist, Lithuanian-born artist, Ernest Zacharevic had produced a sequence of public art in Georgetown, Penang integrating a series of welded iron wall caricatures and mural painting (Fig.2). As to incorporate public art in the urban area, Imageability study and Serial Vision study are frequently used as methods to determine the quality of visual and existing character of urban spaces (Mohd Fabian, 2010 and Tyler, 2013). Both of the studies will lead to a suitability plan of public art placement. Besides, Muhizam (2008) and Pullaro (2013) concur that the present urban morphology needs to be revised to include the land uses, human activities, building form and massing. Additionally, Figure Ground study needs to be integrated into the assessment of public art in a city centre. Thus, this paper is focusing on (i) land uses and activities, (ii) solids, voids, building form and massing, (iii) Imageability study and (iv) Serial Vision study, towards identify the characteristic and morphology of the study area.

(a)

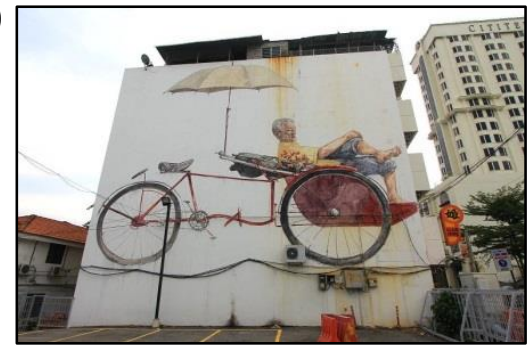

(b)

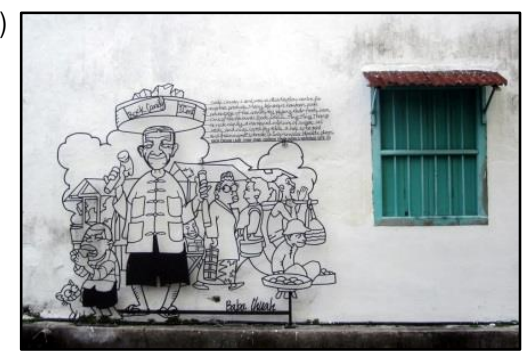

Fig. 2. (a) Expressive Artworks, mural by Ernest Zacharevic; (b) Efficient Artworks, welded iron signage in Georgetown, Penang.

\subsection{Imageability Study}

According to Lynch (1960), imageability is the quality of a physical object that delivers an observer an intense and vivid image while legibility is the easiest way for people to recognize the layout of a place. Besides that, a highly imaginable city would be well-formed, holds very distinct parts and would be immediately recognizable to the people (Erismis \& Gezerman, 2014). Both of them urged that a city grows not only its brand but also its image and desirability of the outer world. The Lynch's theory exerts massive influence, not only in urban design but also more broadly in social science and art history (Raynsford, 2011). There are five elements of legibility recognized; (i) Landmarks, (ii) Nodes, (iii) Districts, (iv) Paths and (v) Edges.

\subsection{Serial Vision Study}

Serial vision happens when a person walks through a town at a uniform speed, and a series of images will reveal (Cullen, 1961). The notion of serial vision is a sequence of static viewpoint frames that positioned in accord with the plan (Blizard \& Fish, 2013). This exercise concerns on the optic, which leads a human movement in a city (Fig. 3). Besides, the place and its contents can be renowned during the Serial Vision study. The place can be recognized throughout response to the human's position in the environment while contents can be determined through examination of the fabrics of town such as colour, texture, scale, style, character, personality and distinctiveness (Wessel et.al, 2008). 


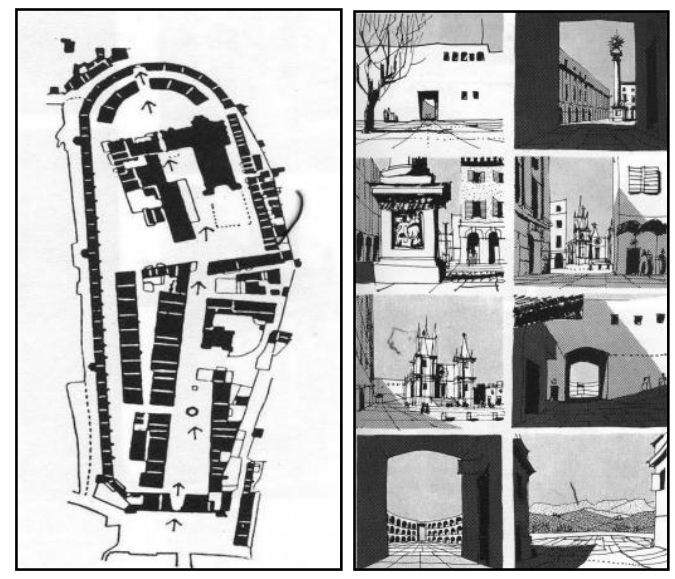

Fig. 3. Serial Vision map and Series of sequential images (Source: Adapted from Cullen,1961).

\subsection{Methodology}

The fieldwork observation to identify the urban morphology of Johor Bahru is conducted within the boundary of Johor Bahru City Centre covering an area of 78.4 acres. It encompassed (i) land uses and activities, (ii) solids, voids, building form and massing, (iii) Imageability study and (iv) Serial Vision study. The rationale of site observation is to determine the existing urban fabric of the study area especially the spirit of the place (genus loci). Observation study was conducted from May 2015 to June 2015 by one observer (the writer). The observation was unanimously held during weekdays and weekend, days (8am to $10 \mathrm{am}$ and $4 \mathrm{pm}$ to $6 \mathrm{pm}$ ) and nights (8pm to 10pm) as to understand and clearly identify the trend and patterns of the human activities and interactions with their surroundings. Tools used during this exercise were a camera (to snap photos of site scenery) base plan of Johor Bahru City Centre (to trace the accurate location of character and urban fabric on the map) and stationeries.

The land use in Johor Bahru City Centre is occupied by commercial and trading activity (Fig. 4a). There are commercial areas being dominated by specific races. Firstly, Chinese commercial area can be found along Jalan Tan Hiok Nee while Indian commercial area is dominant along Jalan Trus and Jalan Ungku Puan. Additionally, there is a river named Sungai Segget across the study area. Previously, it was the nerve of the city and currently under rehabilitation process for a better urban environment accordingly to the Johor Transformation project. This study area is strategically located, which is near Gerbang Selatan Bersepadu (Southern Integrated Gateway) that incorporating the city's main railway station, JB Sentral, and customs, immigration, and quarantine complex (CIQ).

The typological pattern of solids in Johor Bahru is dominated by grid pattern covering commercial shop houses area (Fig. 4b). This grid pattern increases the permeability in Johor Bahru City Centre and easier people access. Urban voids such as Laman Tun Sri Lanang and Legaran Segget provide contrast to the solid urban environment. The different styles of buildings show the evolution of Johor Bahru over the years and become one of the uniqueness of Johor Bahru. There are also public monuments which stand-alone with distinctive features such as Sri Mariamman Temple, Gurdwara Sahib, and Masjid India.

Five elements of legibility were identified in the study area for the Imageability study. Photographs of each element in the study area were taken and sited on the map to produce an Imageability map of Johor Bahru City Centre (Fig. 5a). Additionally, any cultural and heritage values of the element were acknowledged, and it will become a reference to commemorate the history and culture of Johor Bahru City Centre through public art design (Fig. 6). 
(a)

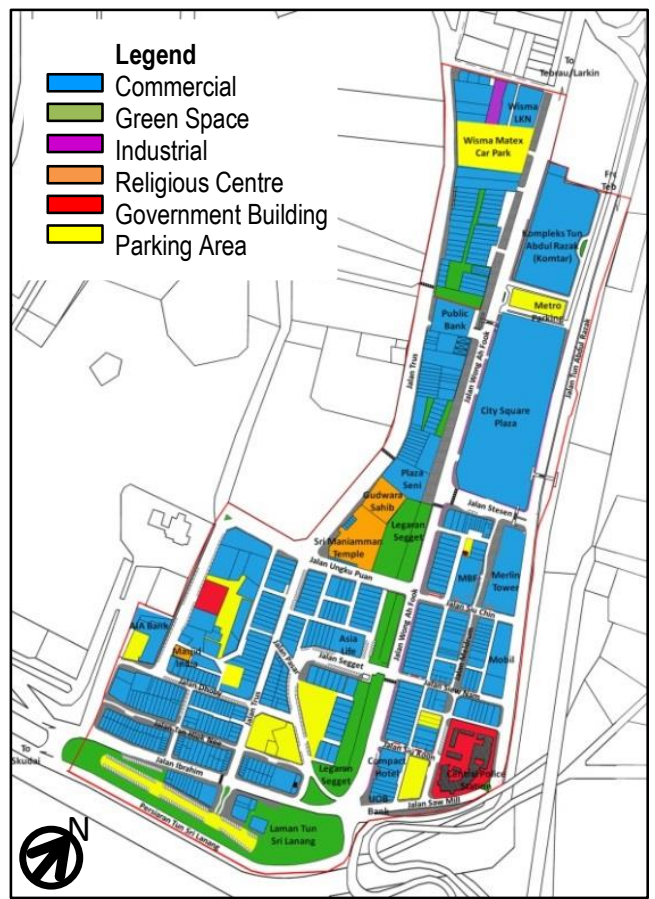

(b)

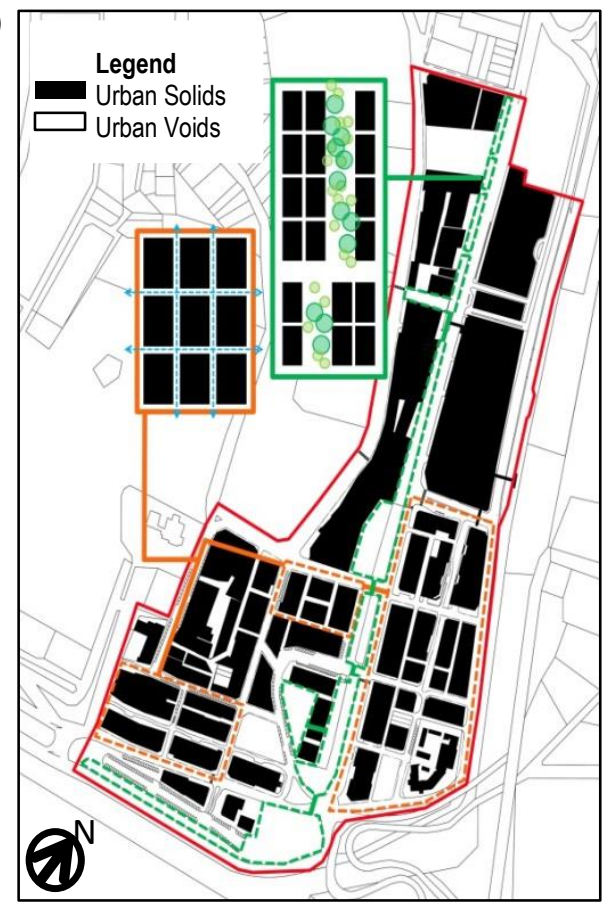

Fig. 4. (a) Land Use map of Johor Bahru City Centre; (b) Urban Solids and Voids map of Johor Bahru City Centre.

(a)

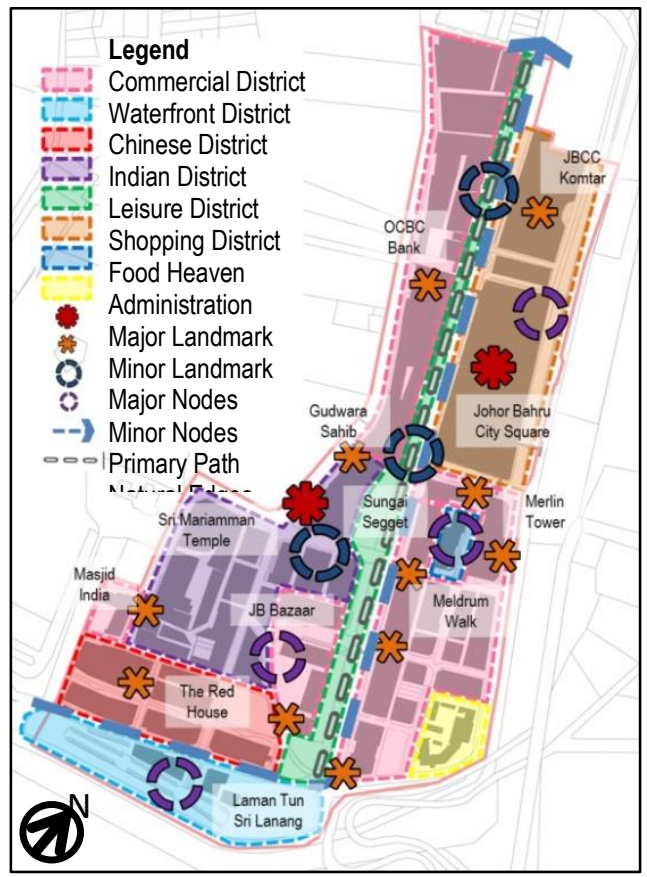

(b)

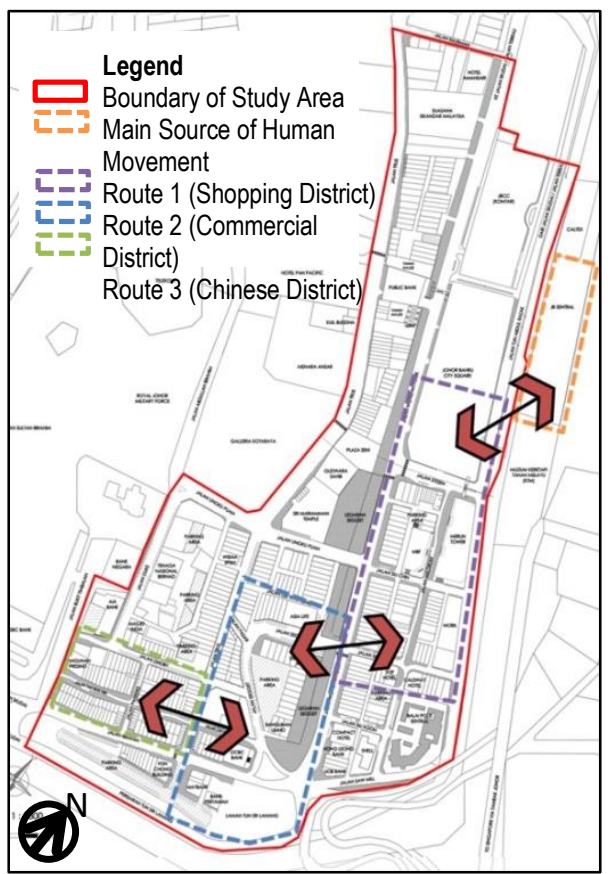

Fig. 5. (a) Imageability map of Johor Bahru City Centre; (b) Serial Vision map of Johor Bahru City Centre. 
(a)

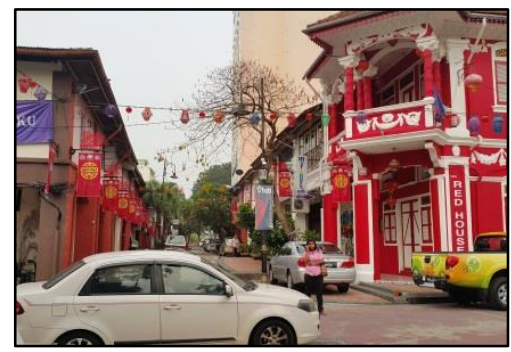

(b)

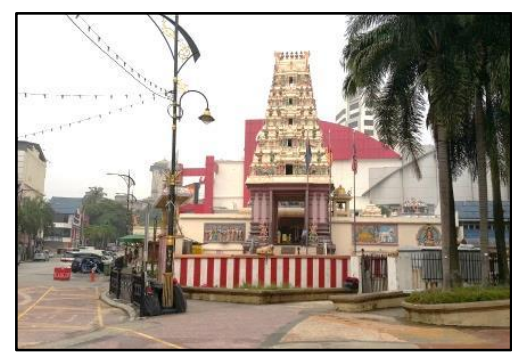

Fig. 6. Cultural and heritage values in Chinese District and Indian District.

For the Serial Vision study, there are three routes selected from the research area. The routes were selected from the districts identified in Imageability Study; (i) Shopping District, (ii) Commercial District and (iii) Chinese District (Fig. 5b). The origins of each route are the source of human movement towards the destination in the study area. The rationale for selecting these routes from three different districts is each of them have a potential to be linked to each other from the main source of human movement (located beside the site boundary), Gerbang Selatan Bersepadu and JB Sentral. As well, the distance of each route is within walkable distance; connecting pedestrian towards varied destinations within a reasonable amount of time and effort, and offering visual interest during the journeys (Southworth, 2005). It will also lead towards any identification of comparison of feeling between the routes chosen. A series of images is taken based on the visual cues that generate human movement from one spot to another spot. The serial images are taken on the eye level, and the visual cues are influenced by the observer's sight. Walking distance for each route is approximately 500 metre (walkable for pedestrian experience). The contents of a place along the routes were perceived as to determine the characteristic or the urban fabric of the town.

\subsection{Findings and discussion}

All the data obtained from observation study are discussed (solely on the writer's judgement as observer) to define the advantages and disadvantages, followed by the synthesis of issues, concerns and opportunities accordingly to the indicators and being adapted into synthesis map to highlight precise location as the essential information for public art incorporation. Table 1 summarized all the main indicators data from the observation study that response to the objective (a) which to determine the characteristic and morphology of study area that significantly contributes to the integration of public art program.

Table 1. Summary of main indicators from observation study.

\begin{tabular}{|c|c|c|c|c|}
\hline Indicators & (i) Land uses and activities & $\begin{array}{l}\text { (ii) Solids, voids, building } \\
\text { form and massing }\end{array}$ & (iii) Imageability Study & $\begin{array}{l}\text { (iv) Serial vision } \\
\text { study }\end{array}$ \\
\hline 1. Advantages & $\begin{array}{l}\text { a. Strongly characterized by } \\
\text { the diverse races' } \\
\text { commercial and trading } \\
\text { b. Lively by pedestrian } \\
\text { activities }\end{array}$ & $\begin{array}{l}\text { a. Many voids for fully utilize } \\
\text { as public space } \\
\text { b. Installation of public art at } \\
\text { the voids area } \\
\text { c. Grid pattern with high } \\
\text { permeability } \\
\text { d. Various building form and } \\
\text { massing accordingly to the } \\
\text { construction era } \\
\text { e. Unique architectural styles }\end{array}$ & $\begin{array}{l}\text { a. Strong landmark; (i) Sri } \\
\text { Mariamman Temple, (ii) } \\
\text { Johor Bahru City Square } \\
\text { b. Heterogeneous of districts } \\
\text { show diversity ethnics, races } \\
\text { and urban activities } \\
\text { c. Some favourable paths } \\
\text { seen as prospect for public } \\
\text { art placement } \\
\text { d. Edges as medium for } \\
\text { public art }\end{array}$ & $\begin{array}{l}\text { a. Every place has its } \\
\text { own character that } \\
\text { showcases the art and } \\
\text { cultural values }\end{array}$ \\
\hline
\end{tabular}




\begin{tabular}{|c|c|c|c|c|}
\hline 2. Disadvantages & $\begin{array}{l}\text { a. Less utilized of public } \\
\text { space } \\
\text { b. Ample parking lots }\end{array}$ & $\begin{array}{l}\text { a. Voids becomes isolated } \\
\text { space because of poor } \\
\text { connectivity } \\
\text { b. Some building façade } \\
\text { create monotonous impact }\end{array}$ & $\begin{array}{l}\text { a. Less utilized of minor } \\
\text { nodes; Laman Tun Sri } \\
\text { Lanang } \\
\text { b. Few aspects of legibility in } \\
\text { Johor Bahru City Centre are } \\
\text { poor }\end{array}$ & $\begin{array}{l}\text { a. Poorly maintained of } \\
\text { some contents } \\
\text { because irresponsible } \\
\text { human behaviour } \\
\text { b. Lack of clear visual } \\
\text { cues }\end{array}$ \\
\hline 3. Issues & $\begin{array}{l}\text { a. Poor linkages or } \\
\text { connectivity results poor } \\
\text { utilized of certain public } \\
\text { spaces }\end{array}$ & $\begin{array}{l}\text { a. Physical character and } \\
\text { linkages influence poor } \\
\text { utilize of voids; (i) Laman } \\
\text { Tun Sri Lanang } \\
\text { b. Public art on urban solids } \\
\text { (building surface) needs } \\
\text { owner authorization }\end{array}$ & $\begin{array}{l}\text { a. Poor imageability that } \\
\text { depicts the diversity and } \\
\text { identity of Johor Bahru } \\
\text { b. Legibility elements are not } \\
\text { effective enough }\end{array}$ & $\begin{array}{l}\text { a. Mood or feeling of } \\
\text { observer depends on; } \\
\text { (i) visual cues and (ii) } \\
\text { contents in a place }\end{array}$ \\
\hline 4. Concerns & $\begin{array}{l}\text { a. Activities that make the } \\
\text { city lively need to be } \\
\text { maintained towards } \\
\text { attracting more visitors; (i) JB } \\
\text { Bazaar, (ii) Food Heaven } \\
\text { area }\end{array}$ & $\begin{array}{l}\text { a. Preservation of heritage } \\
\text { building that present local } \\
\text { distinctiveness; (i) Traditional } \\
\text { Chinese Shop Houses, (ii) } \\
\text { Sri Mariamman Temple }\end{array}$ & $\begin{array}{l}\text { a. Preservation of existing } \\
\text { landmarks that represent } \\
\text { respective districts and act } \\
\text { as route marker } \\
\text { b. Enhancement of several } \\
\text { paths to direct human } \\
\text { movement }\end{array}$ & $\begin{array}{l}\text { a. Variety of contents } \\
\text { enhance the sense of } \\
\text { place } \\
\text { b. Contents of a place } \\
\text { need to be considered } \\
\text { as a guide or } \\
\text { inspiration to design } \\
\text { public art }\end{array}$ \\
\hline 5. Opportunities & $\begin{array}{l}\text { a. Additional public spaces; } \\
\text { (i) rehabilitation of concrete } \\
\text { structure above Sungai } \\
\text { Segget, (ii) transformation of } \\
\text { parking area }\end{array}$ & $\begin{array}{l}\text { a. Multiplicity of building form } \\
\text { and architectural style } \\
\text { inspired public art design } \\
\text { b. Implementation of suitable } \\
\text { public art towards improving } \\
\text { linkages among urban voids }\end{array}$ & $\begin{array}{l}\text { a. Roles of public art to } \\
\text { enhance the image of the } \\
\text { city } \\
\text { b. Integrating public art in } \\
\text { major nodes, favourable } \\
\text { paths and fragmentary edges }\end{array}$ & $\begin{array}{l}\text { a. Reinforce visual } \\
\text { experience for public } \\
\text { b. Possibility to link the } \\
\text { studied routes towards } \\
\text { enhancing the sense } \\
\text { of place and providing } \\
\text { diverse of contents for } \\
\text { public experience }\end{array}$ \\
\hline \multirow[t]{5}{*}{ 6. Synthesis } & $\begin{array}{l}\text { a. Spaces that need to be } \\
\text { connected }\end{array}$ & $\begin{array}{l}\text { a. Voids with high potential to } \\
\text { be designed }\end{array}$ & $\begin{array}{l}\text { a. Nodes for public art } \\
\text { placement }\end{array}$ & $\begin{array}{l}\text { a. Feelings of every } \\
\text { routes }\end{array}$ \\
\hline & $\begin{array}{l}\text { b. Spaces that need to be } \\
\text { maintained }\end{array}$ & $\begin{array}{l}\text { b. Solids with high heritage } \\
\text { and architectural value }\end{array}$ & $\begin{array}{l}\text { b. Landmarks that need to be } \\
\text { embossed }\end{array}$ & $\begin{array}{l}\text { b. Potential public art } \\
\text { trail }\end{array}$ \\
\hline & $\begin{array}{l}\text { c. Spaces that need to be } \\
\text { transformed. }\end{array}$ & & $\begin{array}{l}\text { c. Districts with strong } \\
\text { character }\end{array}$ & \\
\hline & & & d. Favourable path & \\
\hline & & & $\begin{array}{l}\text { e. Natural edges under } \\
\text { rehabilitation }\end{array}$ & \\
\hline
\end{tabular}

Overlay technique is used to determine the suitability of an area for public art placement. This technique is one of the processes to produce suitability map towards a liveable city (objective b). All the synthesis maps from each indicator were used in the overlay technique to generate the final composite map (Fig. 7). The suitability plan identifies the potential areas for development, potential areas for public art placement and trail for public art from the Serial Vision study (Fig. 8). Evidently, the final suitability plan attempt to summarize all of the existing site and contextual condition that could substantially influence the spatial organization and strategic location for public art in Johor Bahru City Centre (Table 2). 


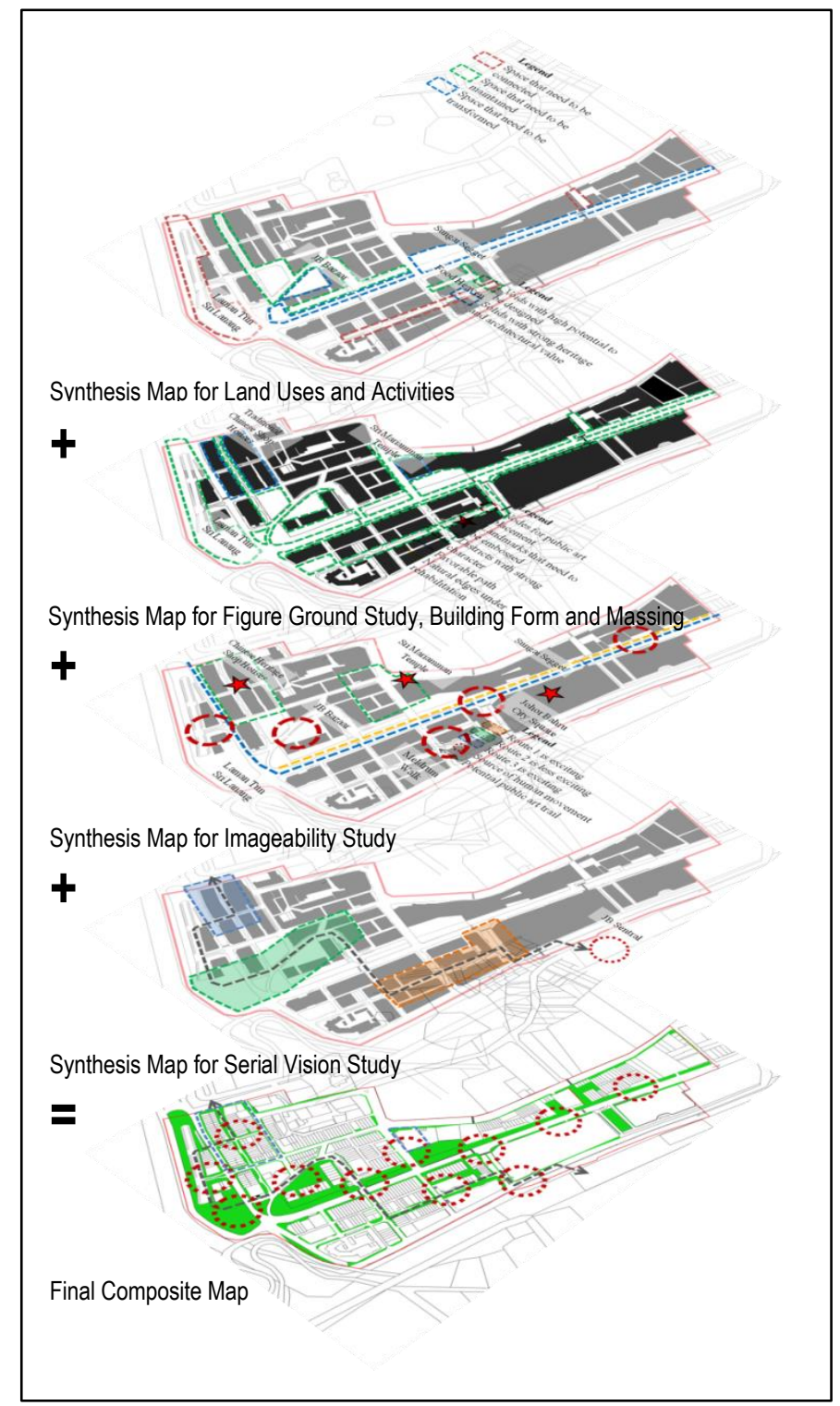

Fig. 7. Overlaying technique to form Final Composite Map. 


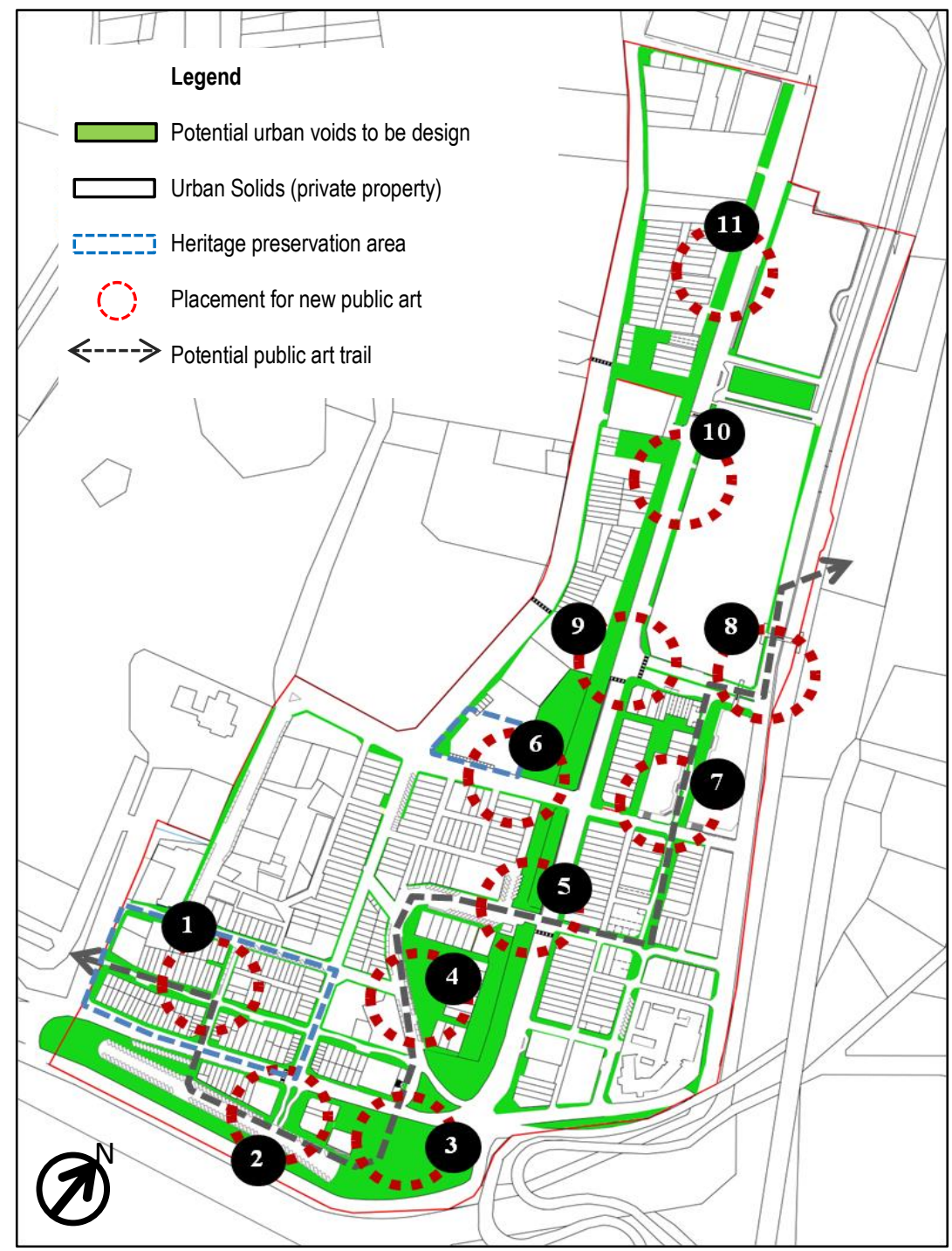

Fig. 8. Final Suitability Plan for public art placement in Johor Bahru City Centre.

Table 2. Descriptions of suitability plan for public art placement.

\begin{tabular}{|c|c|}
\hline Indicators & Descriptions \\
\hline $\begin{array}{l}\text { a. Potential urban } \\
\text { voids to be design }\end{array}$ & $\begin{array}{l}\text { The green areas on the final suitability plan represent urban voids (public space). It suits for public art } \\
\text { placement which accessible for public which offers interaction between the audiences and the artworks. }\end{array}$ \\
\hline $\begin{array}{l}\text { b. Urban solids } \\
\text { (private property }\end{array}$ & $\begin{array}{l}\text { Implementation any form of public art on private property (building surface or private space) need } \\
\text { approval from the owner. It involved participation from various stakeholders including organizer, } \\
\text { selected artists, local authority and the owner of the property. This is important to ensure every } \\
\text { execution of artworks is legal. }\end{array}$ \\
\hline $\begin{array}{l}\text { c. Heritage } \\
\text { preservation area }\end{array}$ & $\begin{array}{l}\text { Two areas were identified as heritage preservation area that has strong character and identical } \\
\text { landmark; (i) Chinese District with The Red House as a landmark and (ii) Indian District with Sri } \\
\text { Mariamman Temple as a landmark. Both areas need to be preserved as they could provide local } \\
\text { distinctiveness. Installation of public art in these areas should celebrate the cultural uniqueness and at } \\
\text { the same time creating harmony in diversity. }\end{array}$ \\
\hline
\end{tabular}




\section{d. Placement for new public art}

Several appropriate public spaces were recognized to locate public art in the city centre and those artworks need to suit its surrounding. There are as follow:

1. Chinese District: Boost the sense of place and rejoice the Chinese culture and heritage that can serve public with additional knowledge.

2. Waterfront District: Placement s series of public art will direct more public to utilize Laman Tun Sri Lanang. The artwork can commemorate the transformation of Johor Bahru from a fishing village into a thriving city centre.

3. Waterfront District: Laman Tun Sri Lanang needs visual cues that can generate public to get there and make the area livelier.

4. Commercial District: The ample parking lots transformed into nodes during the night with lots of trading activities called JB Bazaar or Pasar Karat. Integration of public art at this area could serve more audiences and simultaneously improve the visual sequence for public experience.

5. Leisure District: Rehabilitation of Sungai Segget provides additional spaces for public art in the future. The artworks can memorialize the past of Sungai Segget as nerve of Johor Bahru City Centre towards a public realm for present community.

6. Indian District: Strong character of Indian culture should be maintained and any artworks execute at this area should reflects the Indian heritage and enhance the ambiance.

7. Commercial District and Food Heaven District: The existing contents of place need supervision by local authority to ensure its sustainability. Additional artworks should help to develop the atmosphere of food heaven area and more pedestrian friendly.

8. Shopping District: Artworks need to be interactive and vivid in terms of design as to generate human movement from the JB Sentral and facilitate Johor Bahru City Square as a landmark (Fig. 9a). However, the area is involving the ownership status and need approval from management team.

9. Intersection between Leisure District, Commercial District and Shopping District: This major node with high numbers of pedestrian needs remarkable public art that can symbolize Johor Bahru City Centre as southern gateway of Peninsular Malaysia (Fig. 9b).

10. Shopping District: The main entrance of Johor Bahru City Square should be one of a best place to locate community artwork as it being utilized daily by the public.

11. Leisure District: Placement a series of public art in this area has potential for another public art trail once the rehabilitation process of Sungai Segget finished.

e. Potential public art trail
Placement a sequence of public art along the trail that cut across various districts will improve the visual cues for the public visual experience. The multiplicity of artworks can generate excitement as a pedestrian whilst enhancing the legibility of Johor Bahru City Centre. (a)

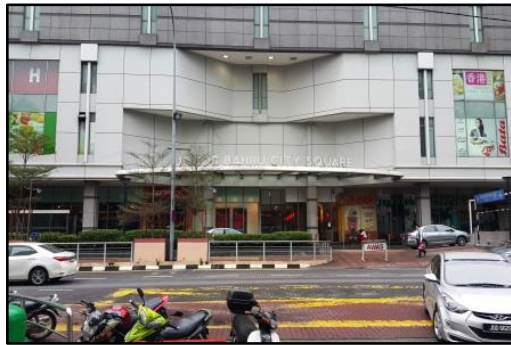

(b)

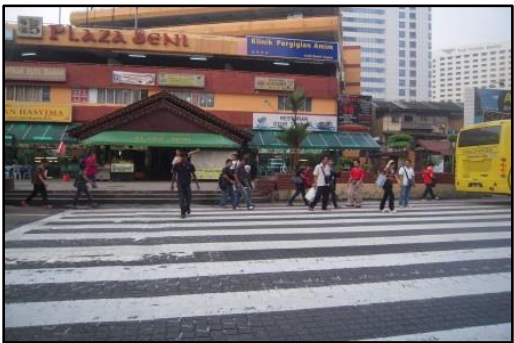

Fig. 9. Potential area for public art placement, (a) Johor Bahru City Centre; (b) Intersection between Leisure District, Commercial District and Shopping District. 


\subsection{Conclusion}

The findings from Observation study indicated public art seems to hold a good prospective in Johor Bahru City Centre based on the characteristic and morphology of contemporary urban environment. Placement of public art at the suitable location has a possibility to create a liveable city and enhance the image of the city itself. All the indicators identified during the exercise; (i) land uses and activities, (ii) solids, voids, building form and massing, (iii) Imageability study and (iv) Serial Vision study, have affirmative results that tend to integrate public art as design solutions. This scenario will lead to the deliberation of design guidelines for public art as it could provide comprehensible practice for all projects. Plenty of private spaces and building façades have potential as medium to incorporate public art.

Notwithstanding the fact that few legibility elements are poor and not effective enough to symbolize the identity of Johor Bahru City Centre, contrariwise there are sufficient areas that have the opportunity to improve the imageability. Public art placements at nodes and along favourable paths have potential to generate interaction between the public and the artworks. Rehabilitation of natural edges (Sungai Segget) that will be partially covered with concrete slab provides ample space for the public realm. Further study after the project finished is needed as it has a possibility for public art locality. The heterogeneous nature of districts has the advantage to propose assorted types of artworks. It will show the interesting and colourful diversity of various ethnicity, races, and urban activities, contained within a city demarcation according to the era. Consequently, the sense of place could be enhanced and simultaneously provide multidimensional visual experience for the public.

Regarding visual sequence, some of the routes studied needs improvement and had a probability becoming a public art trail which links those three routes that cut across a variety of districts. Implementation of suitable artwork on the particular spot could enhance the visual cues and feel, and consequently, divert more public to experience the city as a pedestrian. Thus, a proper guideline for public art is needed as it could succour the planning, installation, and maintenance of the artworks in a city centre.

Through this, the suitable placement of artworks by utilization of urban design knowledge (production of suitability plan using overlaying technique) particularly on the efforts of assessing the adaptable environment could be addressed to improve the imageability and the city growth. The applied perceptive on the public art contribution and urban morphology could provide comprehensive information to the multi-disciplinary professionals primarily to determine appropriate artwork to be integrated into the urban area towards a better environment in a creative manner. Ultimately, participation from all stakeholders is essential to ensure the integration of public art benefits the city and the community for the present and future generations. Future research on public art should investigate the characteristic and morphology of other cities in Malaysia towards identifying any contrast of existing urban spaces; it's social, cultural and environmental aspects.

\section{References}

Australian Institute of Landscape Architecture (2010). Public Art and Landscape. National Policy Statement. Page 1

Blizard, M. \& Fish, C. (2013). An Archaeology of the Street: Analysis of Place in Urbino, Italy. Enquiry / Volume 10 Issue $12013,29-42$

Cardiff Country Council (2005). Cardiff Public Art Strategy. Cardiff Public Art Agency. Page: 17

City of San Diego Commission for Arts and Culture (2004). Public Art Master Plan. City of San Diego. Page 8

Cullen, G. (1961). The Concise Townscape. Taylor \& Francis. Page 2-4,10

Erismis, M. C, Gezerman, A. O. (2014). Analysis of Kadikoy Seashore from the Perspective of Lynch. International Journal of Modern Social Sciences. 2014, 3(2): 75-97

Flynn, B. (2013). City Centre Public Art Plan. City of Sydney Council. Page 5

Irish Museum of Modern Art (2008). What is Public Art?. Irish Museum of Modern Art (IMMA). Page 4 
Lynch, K. (1960). Image of the City. Legibility and Imageability. MIT Press Page 4,6-9,10,12

Mohd Fabian, H. (2010). Towards Integrating Public Art in Malaysian Urban Landscape. Pertanika J. Soc. Sci. \& Hum. Page: 251-264

Muhizam, M. (2008). Public Art in the Federal Territory of Putrajaya: Questions of Value and Role. Wacana Seni Journal of Arts Discourse. Jil./Nol.8. Page: 2

Nurul Izzah, A. B., Mazlina, M. \& Nor Zalina, H. (2014) Vertical Greenery System as Public Art? Possibilities and Challenges in Malaysian Urban Context. Procedia - Social and Behavioral Sciences. Volume 153, 16 October 2014, Pages 230-241

Pullaro, C. (2013). Public Art Master Plan, City of John Creek, Georgia. Leadership John Creek. Page 6-7

Raynsford, A. (2011). Civic Art in an Age of Cultural Relativism: The Aesthetic Origins of Kevin Lynch's Image of the City. Journal of Urban Design, February 2011, Vol. 16. No. 1, 43-65

Southern Johor Economic Region (SJER). (2006). Comprehensive Development Plan 2006-2025. Part 3 Physical Planning Initiatives. Page 13-7

Southworth, M. (2005). "Designing the Walkable City." J. Urban Plann. Dev., 10.1061/(ASCE)0733-9488(2005)131:4(246), $246-257$.

Tyler, J. (2013) Public Art Master Plan, City of Coronado. Cultural Arts Commission. Page 6, 9

Wessel, G., Sauda, E. \& Chang R. (2008) Urban Visualization: Urban Design and Computer Visualization. CAADRIA 2008 (Proceedings of the $13^{\text {th }}$ International Conference on Computer Aided Architectural Design Research in Asia) Chiang Mai (Thailand) 9-12 April 2008. Page 409-416 